Article

\title{
Comparison of Wood Quality of Douglas Fir and Spruce from Afforested Agricultural Land and Permanent Forest Land in the Czech Republic
}

\author{
Aleš Zeidler *, Vlastimil Borůvka (1) and Ondřej Schönfelder \\ Department of Wood Processing, Faculty of Forestry and Wood Sciences, \\ Czech University of Life Sciences Prague, Prague 16500, Czech Republic; boruvkav@fld.czu.cz (V.B.); \\ schonfelder@fld.czu.cz (O.S.) \\ * Correspondence: zeidler@fld.czu.cz; Tel.: +420-224-383-742
}

Received: 12 November 2017; Accepted: 19 December 2017; Published: 25 December 2017

\begin{abstract}
This study compares the quality of wood from two distinct sites in the Czech Republic-from former afforested agricultural land and forest land. We compared the properties of Norway spruce wood (Picea abies Karst.) and Scots pine wood (Pinus sylvestris L.), the most important domestic tree species, to Douglas fir (Pseudotsuga menziesii (Mirbel) Franco), a North American tree species and a potential substitute for the domestic spruce. Wood density, modulus of elasticity (MOE), modulus of rupture (MOR) and impact bending strength were the properties tested that were used for comparing tree species. Without taking into consideration the site, the highest density values from the tested tree species were obtained for Douglas fir $\left(0.568 \mathrm{~g} \cdot \mathrm{cm}^{-3}\right)$, followed by the pine $\left(0.508 \mathrm{~g} \cdot \mathrm{cm}^{-3}\right)$ and the spruce $\left(0.463 \mathrm{~g} \cdot \mathrm{cm}^{-3}\right)$. The Douglas fir also dominated in the remaining assessed properties, whilst the influence of site was not confirmed, with the exception of MOE and MOR, and only for the Douglas fir wood, wherein higher values were obtained for forest land. In terms assessed Douglas fir properties, it exceeds the domestic softwoods and represents a possible suitable replacement for them. The site only plays a role in terms of the Douglas fir, and only for certain properties.
\end{abstract}

Keywords: afforested farm land; Douglas fir; Norway spruce; Scots pine; wood properties; density; modulus of rupture

\section{Introduction}

As in other European countries, the afforested area is increasing steadily in the Czech Republic. It has increased from approximately $25 \%$ to $34 \%$ at present since midway through the 18th century. After medieval deforestation, large areas were reforested again for production purposes. The most extensive afforestation effort took place after the Second World War (1939-1945), when large areas were afforested in regions with former German settlement [1], and the area of forest lands continued to increase during the remainder of the 20th century, reaching its peak in 1991 after a huge transformation of the farm sector [2].

Douglasfir is the most popular and utilized introduced tree species in Europe, including in the Czech Republic, and it has the highest production potential among the native and introduced tree species [3]. It very often represents planted and cultivated species, especially in France, Germany, Italy and the United Kingdom [4]. In the Czech Republic, the area is only represented by some 5800 ha, increasing by approximately 100 ha per year [5,6]. Its role is particularly assumed as a substitute for the declining Norway spruce, which is endangered by climatic changes at lower altitudes [7], and this species, native on some $11-15 \%$ of the Czech territory, shows many health problems, yet is at the same time the key species of Mid-European forestry [8,9]. The supply of Norway spruce timber will likely decrease in the near future [10]. Afforestation of agricultural lands constitutes a serious change in 
soil dynamics, including soil structure, organic matter and nutrient dynamics [11-14]. Compared to Norway spruce, Douglas fir shows less negative effects on the forest soil $[15,16]$ and herb vegetation layer [17], and thus Douglas fir can represent a very convenient substitute for declining spruce, at least as a part of its non-native range in commercial forests [18]. Douglas fir also appears promising under local conditions in terms of wood quality [19].

There are very few works that have evaluated the properties of wood from former agricultural land in the Czech Republic and other European countries. Most of the works deal with tree species growth, volume production or health status, and at present there is only one study from the Czech Republic dealing with spruce wood quality from afforested agricultural land [20]. Within the wider region, Polish studies are available on wood properties of pine from agricultural land [21,22]. In Sweden, Johansson [23] dealt with the impact of these specific sites on the quality of spruce wood.

The aim of this study is to evaluate the quality of Douglas fir wood growing on a site formerly used as agricultural land. Based on wood density, impact bending strength, bending strength and MOE, the work assesses the extent to which such habitat types are suitable for the production of quality wood and, in particular, assesses the suitability of Douglas fir for substitution of spruce wood, the original and currently the most widely used coniferous species in the Czech Republic on wooded former agricultural land. The variability of the properties in relation to the position in the stem and the influence of the density on the strength characteristics were also evaluated.

\section{Materials and Methods}

\subsection{Materials}

For the purpose of this study, 2 different sites in the Central Bohemia area (Czech Republic) were selected. The first site, Krymlov (49.9460656 N, 14.9257086 E), represents forested agricultural land (AL). The growth is a mixture of spruce, Scots pine, white birch and Douglas fir at a site characterized by an altitude of $430 \mathrm{~m}$ above sea level, an annual average temperature of $7.5^{\circ} \mathrm{C}$ and $600 \mathrm{~mm}$ of annual precipitation. The soil type is characterized as Gleyed Luvisol to Luvic Gley. Under these conditions, the tree species reached a standing volume in the following order: pine, spruce, birch and Douglas fir $352,349,157$ and $438 \mathrm{~m}^{3} \cdot \mathrm{ha}^{-1}$, and Douglas fir thus clearly represented the most productive tree species from all tested species [24].

The second study plot, Amerika (50.0072625 N, $14.8537100 \mathrm{E})$, represents reference growth on permanent forest land (FL), i.e., the forest continuity has never been interrupted at the site. This is a stand with Norway spruce and Douglas fir. The site is relatively acidic, characterized by an altitude $420 \mathrm{~m}$ above sea level, a mean annual temperature of $8.5^{\circ} \mathrm{C}$ and precipitation of $550-650 \mathrm{~mm}$ per year. The soil is a Luvisol. The standing volume was $507 \mathrm{~m}^{3} \cdot \mathrm{ha}^{-1}$ for spruce and $579 \mathrm{~m}^{3} \cdot \mathrm{ha}^{-1}$ for Douglas fir [15]. The age of all felled trees at both sites was around 60 years.

A total of four sample trees of Douglas fir, four samples trees of spruce and four samples trees of pine trees were taken. An equivalent number of Douglas fir and spruce samples were taken on the former afforested agricultural land for comparison with the neighbouring reference forest land. Unfortunately, it was not possible to find forest soil in the adjoining afforested agricultural land with a mixture of Douglas fir-spruce-pine; however, we considered it a shame not to take advantage of the possibility of assessing the quality of the pine wood from the agricultural land, and it was at least partially included in the evaluation.

The basic forest characteristics of the specimens, i.e., the range of heights and enumeration diameter according to tree species and site, are shown in Table 1. 
Table 1. Height and diameter of the sample trees.

\begin{tabular}{ccccc}
\hline \multirow{2}{*}{ Species } & \multicolumn{2}{c}{ Agricultural Land (AL) } & Forest Land (FL) \\
\cline { 2 - 5 } & Height $(\mathbf{m})$ & Breast-Height Diameter $\mathbf{( c m )}$ & Height $\mathbf{( m )}$ & Breast-Height Diameter $(\mathbf{c m})$ \\
\hline Douglas fir & $25.1-27.5$ & $26.4-31.6$ & $29.7-35.8$ & $30.3-40.5$ \\
Spruce & $23.0-28.0$ & $20.9-32.0$ & $25.0-29.8$ & $28.2-31.6$ \\
Pine & $24.2-27.2$ & $22.0-29.6$ & - & - \\
\hline
\end{tabular}

\subsection{Methods}

Sections (120 cm in length) were taken from each sample tree, representing the basal part of the stem and $20 \%, 40 \%$ and $60 \%$ of the tree height, marked as vertical positions (VP) 1, 2, 3 and 4 in respective order. The sections were cut using a band saw in order to obtain the central plank. The central plank was then the starting material for the production of test specimens for the appropriate tests and assessments of the influence of the horizontal position (HP), where position 1 denotes the part closest to the centre of the stem, whilst the position with the highest number indicates the part near the bark. The length of the test specimens differed depending on the test, but the cross-section area of $20 \times 20 \mathrm{~mm}$ (radial $\times$ tangential) was the same for all tests.

For the purpose of evaluating the investigated tree species and the impact of site, we tested the following physical and mechanical wood properties. For physical properties, wood density was evaluated on specimens at $12 \%$ moisture content after conditioning at $20^{\circ} \mathrm{C}$ and $65 \%$ relative humidity, and a total of 3695 specimens measuring $20 \times 20 \times 30 \mathrm{~mm}$ were used to determine the density according to the Czech national standard [25]. Density (in $\mathrm{g} \cdot \mathrm{cm}^{-3}$ ) was calculated according to the following formula:

$$
\rho_{12}=\frac{m_{12}}{a_{12} \cdot b_{12} \cdot l_{12}}
$$

where $\rho_{12}$ is the density at a wood moisture content of $12 \%, m_{12}$ is the mass of the test samples $(\mathrm{g})$ at a wood moisture of $12 \%$, and $a_{12}, b_{12}$, and $l_{12}$ are the dimensions of the test samples $(\mathrm{cm})$ at a wood moisture of $12 \%$.

For mechanical properties, modulus of elasticity in bending (MOE), modulus of rupture (MOR) and impact bending strength were evaluated. The tests for mechanical properties were evaluated on specimens at $12 \%$ of moisture content after conditioning at $20{ }^{\circ} \mathrm{C}$ and $65 \%$ relative humidity according to the Czech national standard [26]. Specimens measuring $20 \times 20 \times 300 \mathrm{~mm}$ were used for all of the specified tests.

MOE was determined and evaluated according to the Czech national standard [27]. A total of 1139 specimens were used. MOE (in MPa) was calculated according to the following formula:

$$
M O E=\frac{\Delta F \cdot l_{0}^{3}}{4 \cdot b \cdot h^{3} \cdot \Delta y}
$$

where $\Delta F$ is the difference between the forces at maximum and minimum load limits $(\mathrm{N}), l_{0}$ is the distance between the supports $(\mathrm{mm}), b$ and $h$ are the width and height $(\mathrm{mm})$, respectively, of the test samples, and $\Delta y$ is the test sample deflection $(\mathrm{mm})$ in the area of pure bending, equal to the difference between the bending values corresponding to maximum and minimum load limits.

MOR was determined and evaluated according to the Czech national standard [28]. A total of 1139 specimens were used. MOR (in MPa) was calculated according to the following formula:

$$
\operatorname{MOR}=\frac{3 \cdot F_{\max } \cdot l_{0}}{2 \cdot b \cdot h^{2}}
$$

where $F_{\max }$ is the maximum load $(\mathrm{N}), l_{0}$ is the distance between the two supports (mm), and $b$ and $h$ are the respective width and height $(\mathrm{mm})$ of the test samples. 
Impact bending strength was determined and evaluated according to the Czech national standard [29]. A total of 2005 specimens were used, and impact bending strength (in $\mathrm{J} \cdot \mathrm{cm}^{-2}$ ) was calculated according to the following formula:

$$
A=\frac{W}{b \cdot h}
$$

where $W$ is the power consumed for the wood rupture $(\mathrm{J})$, and $b$ and $h$ are the test sample dimensions $(\mathrm{cm})$ in the radial and tangential directions respectively.

Statistically significant differences in the assessed wood properties between tree species within one site, and differences between the same tree species depending on the site, or the influence of other factors such as vertical position and horizontal position in the stem, were assessed using ANOVA and subsequently, Tukey's multiple-range test. A significance level $\alpha=0.05$ was used as the default value. A linear regression model was used to assess the effect of density on the strength characteristics.

Due to the fact that pine was only represented on agricultural land and was missing from the reference site, the values obtained were those used only for comparison with other tree species within sites and for comparison with literature. Pine was not used to evaluate the impact of sites.

\section{Results}

\subsection{Density}

The highest wood density value was exhibited by Douglas fir for both of the assessed sites, followed by the pine, while the lowest density value was obtained by the spruce for both sites. The differences between individual species within sites were statistically significant, but the difference is also apparent from the point of view of their use in the woodworking industry, especially between the spruce and the Douglas fir. According to our results, the origin of a site does not affect density (Figure 1). No statistically significant difference was proven for any of the tree species (see Table 2).

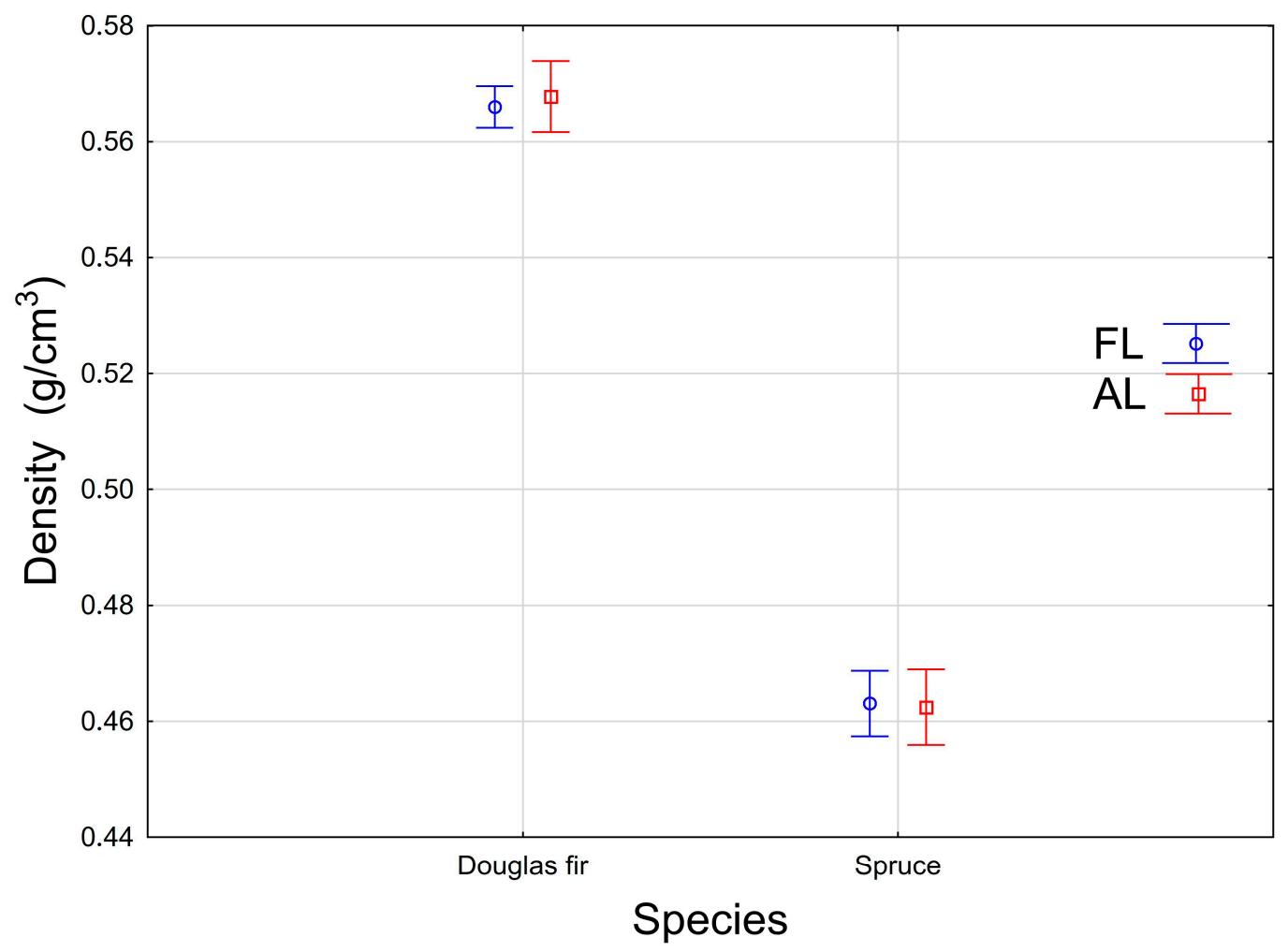

Figure 1. Impact of site on wood density. 
Table 2. Wood density (in $\mathrm{g} \cdot \mathrm{cm}^{-3}$ ) of individual tree species according to the evaluated sites.

\begin{tabular}{ccccccc}
\hline Site & Species & Mean & Minimum & Maximum & Std. Dev. & Coef. Var. \\
\hline \multirow{2}{*}{ AL } & Douglas fir & 0.568 & 0.420 & 0.710 & 0.059 & 10.3 \\
& Spruce & 0.463 & 0.367 & 0.628 & 0.043 & 9.3 \\
& Pine & 0.508 & 0.372 & 0.703 & 0.067 & 13.2 \\
FL & Douglas fir & 0.566 & 0.349 & 0.776 & 0.090 & 16.0 \\
& Spruce & 0.463 & 0.363 & 0.605 & 0.050 & 10.9 \\
\hline
\end{tabular}

\subsection{Stiffness}

Similar to density, the highest MOE value was obtained for Douglas fir wood, again at both sites. Unlike density, the second highest value was obtained by the spruce, and the lowest value by the pine. In terms of processing and utilization, pine wood is the least flexible; however, no statistically significant difference was found between spruce and pine, and Douglas fir clearly differs from both species. In the case of MOE, the sites had an impact, but only in the case of the Douglas fir (Figure 2). The Douglas fir achieves a higher MOE value on forest soil (see Table 3).

Table 3. Modulus of elasticity (in MPa) of individual tree species according to the evaluated sites.

\begin{tabular}{ccccccc}
\hline Site & Species & Mean & Minimum & Maximum & Std. Dev. & Coef. Var. \\
\hline AL & Douglas fir & 8940 & 3579 & 13,328 & 2129 & 23.8 \\
& Spruce & 7541 & 3619 & 11,866 & 1422 & 18.9 \\
& Pine & 7263 & 3377 & 13,792 & 2260 & 31.1 \\
FL & Douglas fir & 9783 & 3497 & 16,408 & 3000 & 30.7 \\
& Spruce & 7744 & 4838 & 12,309 & 1732 & 22.4 \\
\hline
\end{tabular}

AL—agricultural land, FL—forest land, Std. Dev.—standard deviation, Coef. Var-—coefficient of variation.

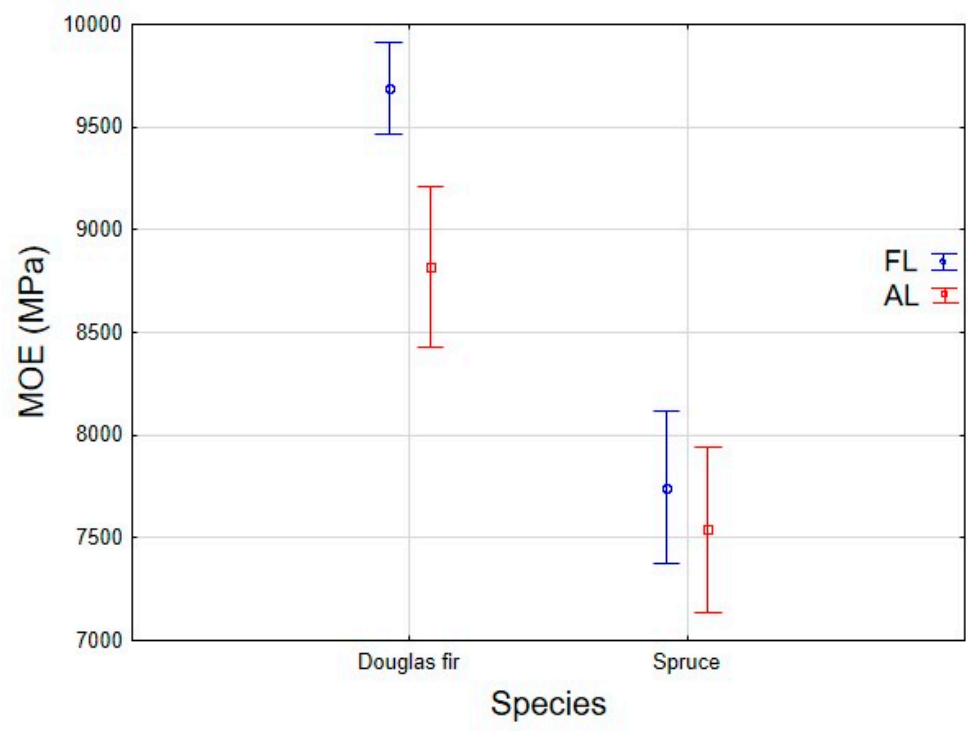

Figure 2. Impact of site on modulus of elasticity.

\subsection{Bending Strength}

The Douglas fir wood once again dominates in terms of bending strength at both sites. On the former agricultural land, pine obtained the second highest value. However, this value is not statistically significant compared to the spruce that obtained the lowest value. The influence of the site on bending 
strength is conclusive for Douglas fir wood, whereas for the spruce, the influence of the site was not confirmed (Figure 3 ) and the values are practically identical (see Table 4).

Table 4. Bending strength (in MPa) of individual tree species according to the evaluated site.

\begin{tabular}{ccccccc}
\hline Site & Species & Mean & Minimum & Maximum & Std. Dev. & Coef. Var. \\
\hline \multirow{2}{*}{ AL } & Douglas fir & 70 & 20 & 115 & 17 & 24.3 \\
& Spruce & 58 & 35 & 97 & 10 & 17.9 \\
& Pine & 63 & 33 & 115 & 16 & 25.2 \\
FL & Douglas fir & 76 & 20 & 138 & 29 & 37.6 \\
& Spruce & 58 & 32 & 92 & 11 & 19.6 \\
\hline
\end{tabular}

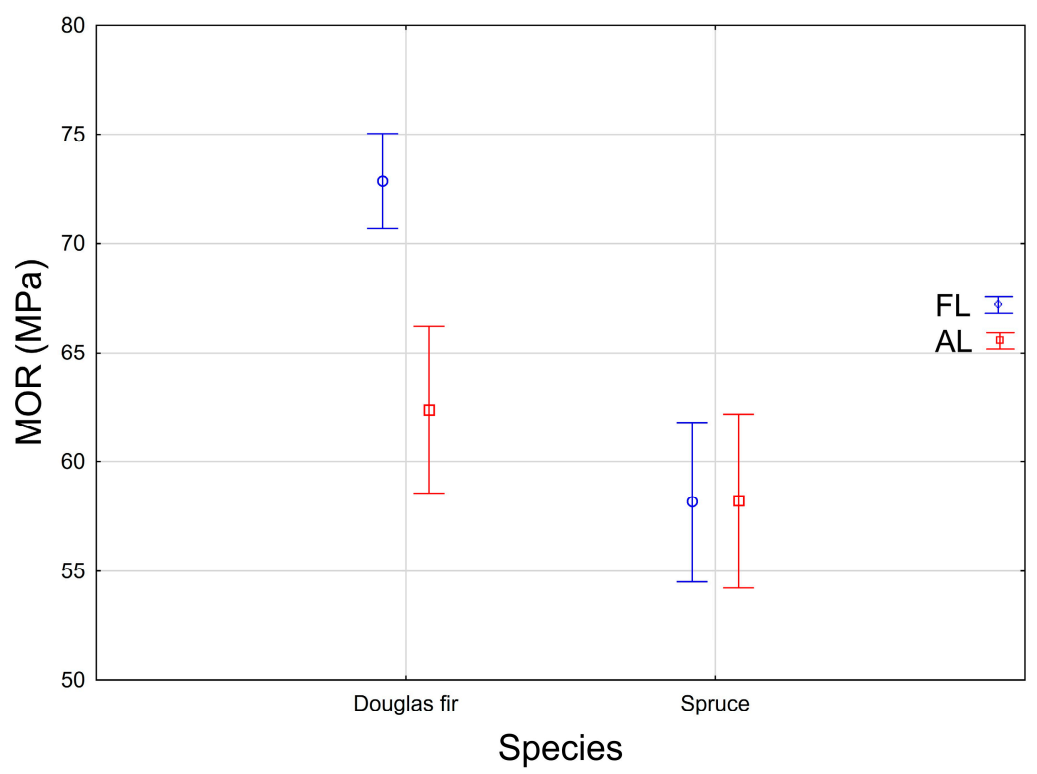

Figure 3. Impact of site on modulus of rupture.

\subsection{Impact Bending Strength}

In terms of impact bending strength, similar to all other tested properties, Douglas fir wood obtained the highest values regardless of site. The value represents almost twice the value for spruce and pine and is statistically significant, and Douglas fir wood therefore better resists dynamic loads than domestic tree species. The values for spruce and pine differ only slightly and are essentially identical in terms of statistics (see Table 5). The impact of sites on Douglas fir or the spruce was not confirmed (Figure 4).

Table 5. Impact bending strength (in $\mathrm{J} \cdot \mathrm{cm}^{-2}$ ) of individual tree species according to the evaluated site.

\begin{tabular}{ccccccc}
\hline Site & Species & Mean & Minimum & Maximum & Std. Dev. & Coef. Var. \\
\hline \multirow{2}{*}{ AL } & Douglas fir & 5.4 & 1.3 & 18.9 & 2.9 & 53.7 \\
& Spruce & 2.9 & 1.3 & 8.1 & 1.4 & 46.1 \\
\multirow{2}{*}{ FL } & Pine & 3.1 & 1.3 & 7.1 & 1.3 & 43.5 \\
& Douglas fir & 5.3 & 1.3 & 20.8 & 2.9 & 55.4 \\
& Spruce & 2.8 & 1.3 & 10.9 & 1.3 & 45.8 \\
\hline
\end{tabular}

AL—agricultural land, FL—forest land, Std. Dev.-standard deviation, Coef. Var.-coefficient of variation. 
Another factor that greatly contributes to the variability of the evaluated properties, regardless of tree species or site, is the position in the stem. As expected, the influence of the horizontal position was clearly demonstrated, where the lowest values are obtained in the centre of the stem, and the values increase in the direction to the bark. This is particularly striking in the Douglas fir and the pine. Figure 5 shows the course of density depending on the position in the stem according to the tree species. There is a similar layout trend for MOE, MOR and impact bending strength, while the influence of the vertical position proved to be ambiguous and it was not possible to trace any characteristic course.

Since density is often understood as a basic indicator of mechanical properties of wood, we were interested in how much the density value correlates with the strength and elastic properties of wood. Regarding the evaluated properties, the tightest correlation is between density and bending strength, as shown in Figure 6 for spruce wood; a similar trend was found for other species as well, and the tightest dependency ratio pertains to the pine $\left(R^{2}=0.57\right)$, followed by the spruce $\left(R^{2}=0.55\right)$ and the Douglas fir $\left(R^{2}=0.53\right)$ (see Table 6, bold text).

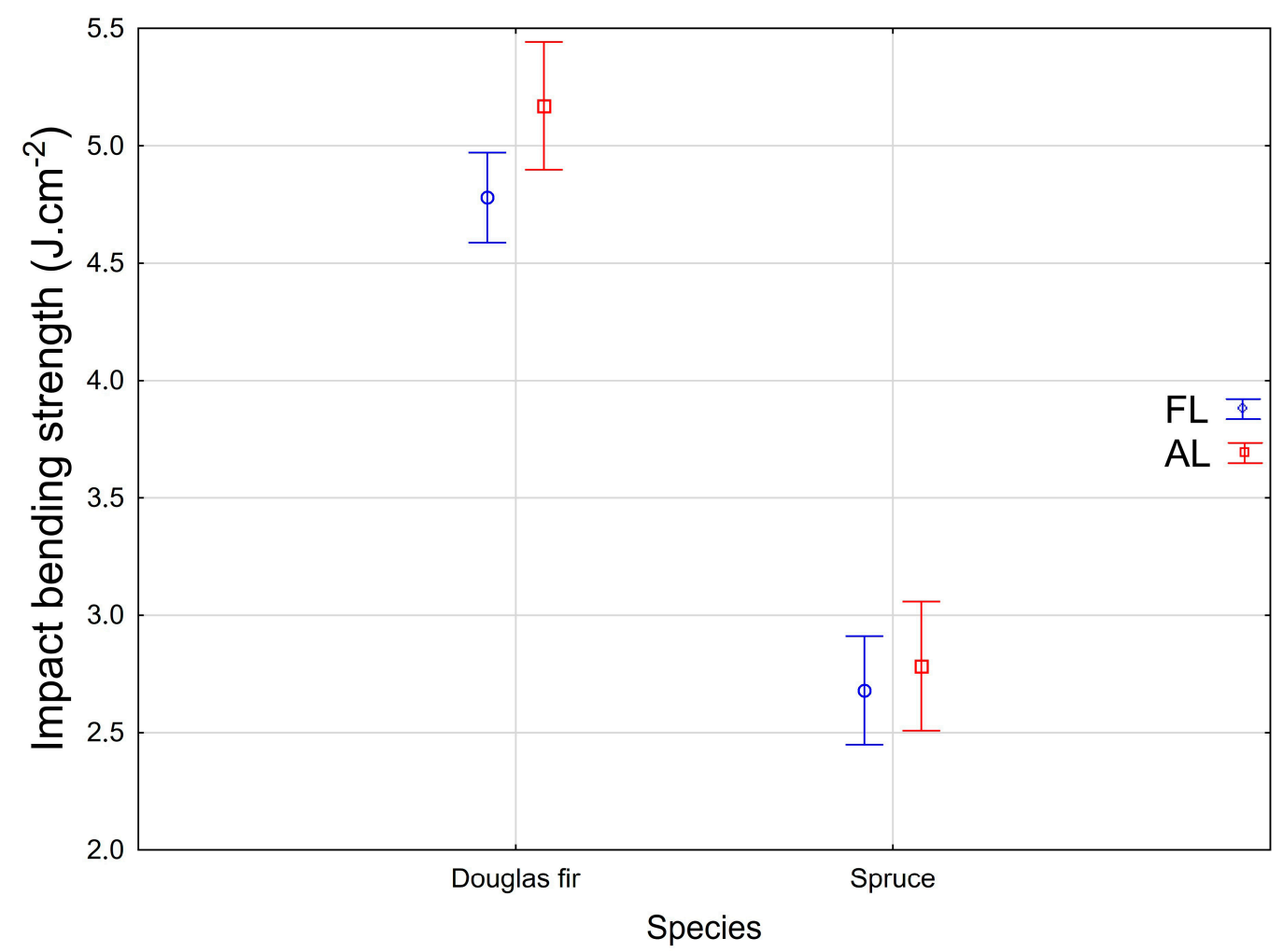

Figure 4. Impact of site on impact bending strength. 


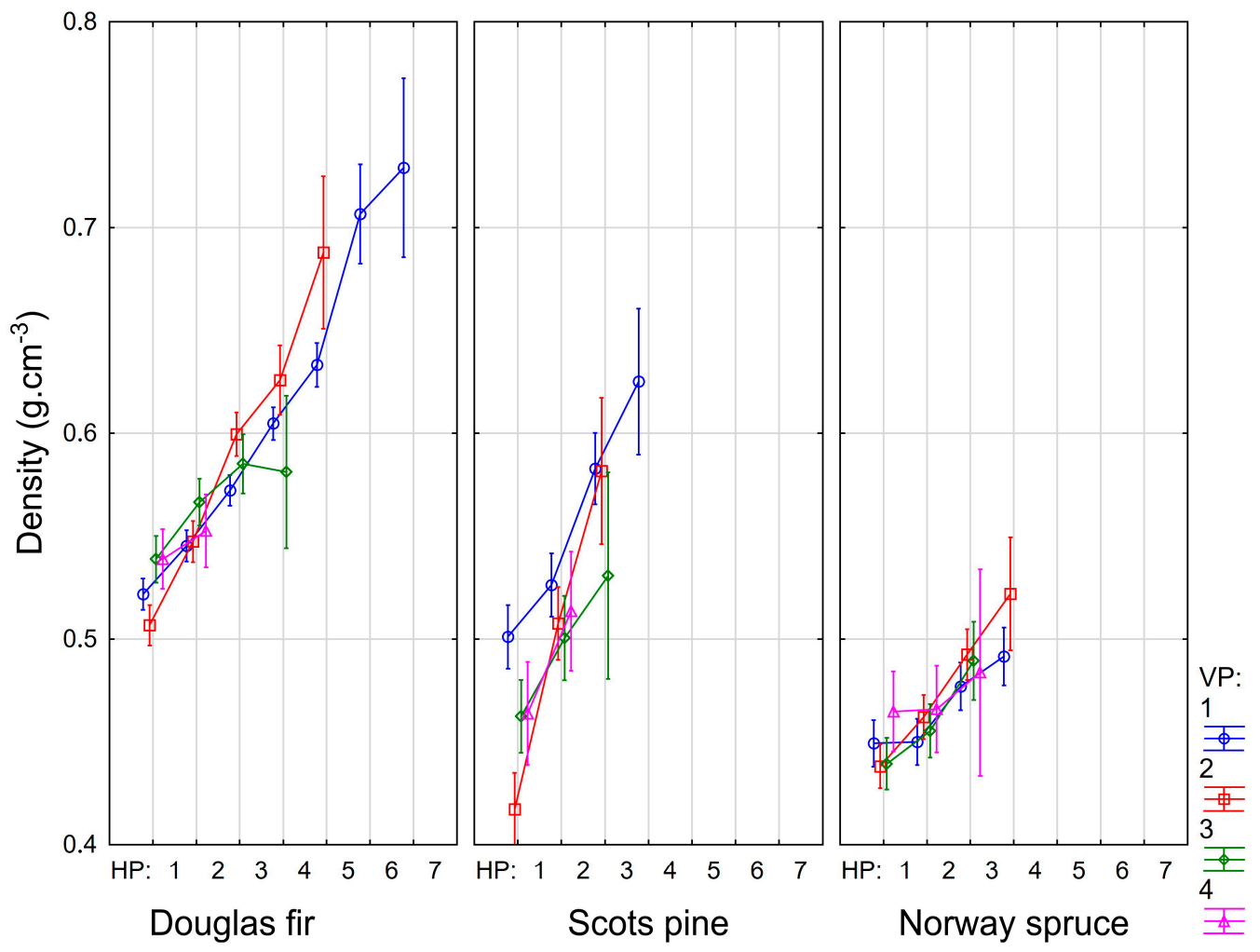

Figure 5. Within stem variability of wood density (HP-horizontal position, VP—vertical position).

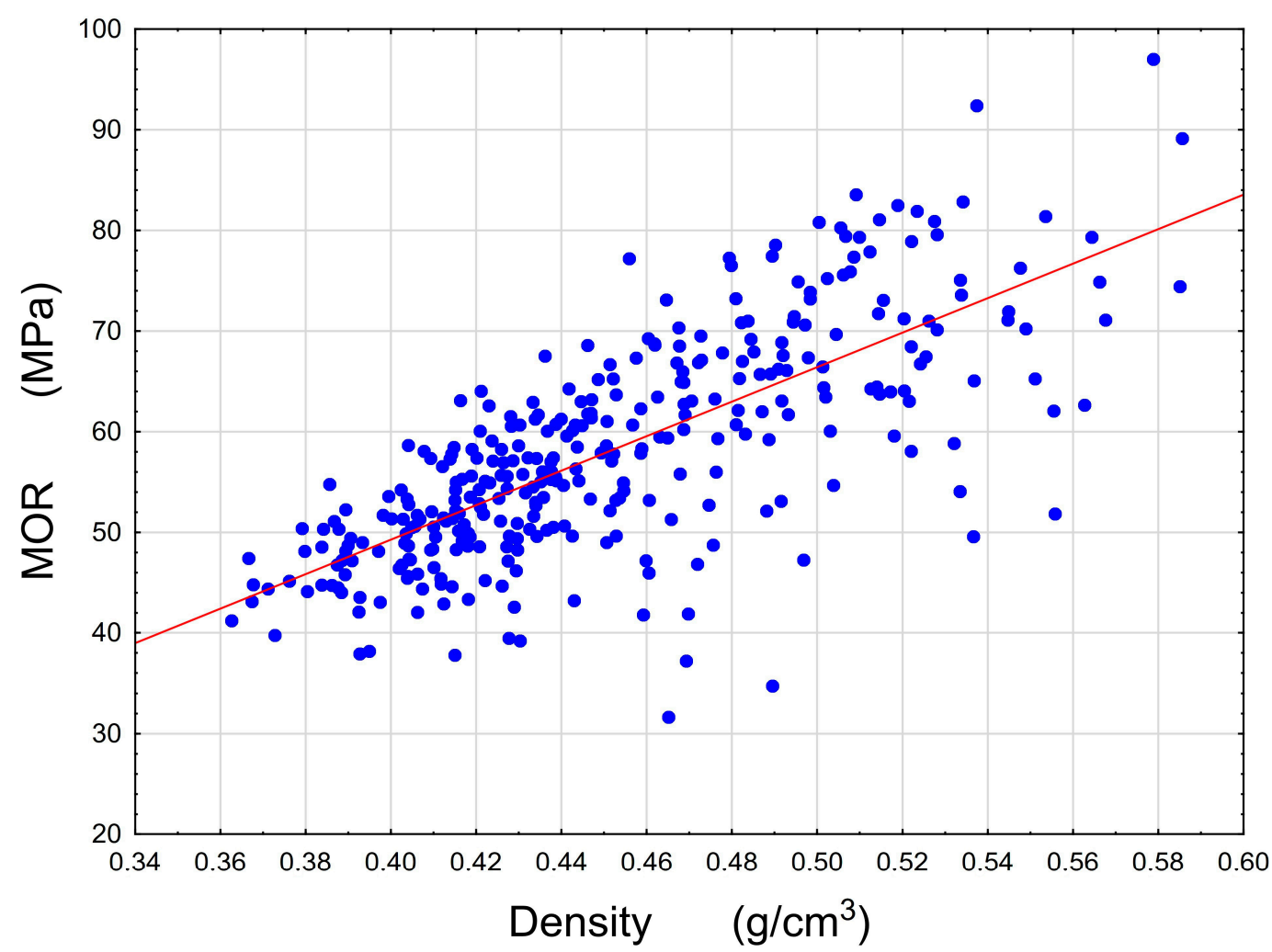

Figure 6. Dependence of bending strength of spruce wood on density. 
Table 6. Correlation between density and the tested mechanical properties.

\begin{tabular}{|c|c|c|c|c|}
\hline Site & Species & Property & Equation & $R^{2}$ \\
\hline \multirow[t]{3}{*}{ All sites together } & Douglas fir & $\mathrm{MOE}$ & $y=-2189.2213+20332.432 x$ & 0.3718 \\
\hline & & MOR & $y=-23.4424+163.4766 x$ & 0.5254 \\
\hline & & Impact bending & $y=-9.7083+25.6969 x$ & 0.3036 \\
\hline \multirow[t]{3}{*}{$\mathrm{AL}$} & & MOE & $y=-2365.5407+20124.4382 x$ & 0.3116 \\
\hline & & MOR & $y=-26.1686+167.8107 x$ & 0.4920 \\
\hline & & Impact bending & $y=-10.9906+28.4252 x$ & 0.2809 \\
\hline \multirow[t]{3}{*}{ FL } & & MOE & $y=-2286.3502+20828.2863 x$ & 0.4193 \\
\hline & & MOR & $y=-22.5079+162.0742 x$ & 0.5404 \\
\hline & & Impact bending & $y=-9.2892+24.6411 x$ & 0.3259 \\
\hline \multirow[t]{3}{*}{ All sites together } & Spruce & MOE & $y=-2539.8725+22545.5831 x$ & 0.4433 \\
\hline & & MOR & $y=-19.2747+171.3528 x$ & 0.5466 \\
\hline & & Impact bending & $y=-0.9248+8.074 x$ & 0.0827 \\
\hline \multirow[t]{3}{*}{$\mathrm{AL}$} & & MOE & $y=-1214.9088+19405.4877 x$ & 0.3168 \\
\hline & & MOR & $y=-20.7826+175.07 x$ & 0.4803 \\
\hline & & Impact bending & $y=-1.1198+8.6408 x$ & 0.0754 \\
\hline \multirow[t]{3}{*}{ FL } & & MOE & $y=-3200.672+24175.9315 x$ & 0.5230 \\
\hline & & MOR & $y=-18.5565+169.4517 x$ & 0.5939 \\
\hline & & Impact bending & $y=-0.8107+7.724 x$ & 0.0879 \\
\hline \multirow[t]{3}{*}{$\mathrm{AL}$} & Scots pine & MOE & $y=-4805.5192+24429.0212 x$ & 0.4667 \\
\hline & & MOR & $y=-30.24+188.2447 x$ & 0.5676 \\
\hline & & Impact bending & $y=-4.1252+13.9913 x$ & 0.4892 \\
\hline
\end{tabular}

AL-agricultural land, FL-forest land.

\section{Discussion}

Alden [30] specifies the highest value for coastal Douglas fir of $0.570 \mathrm{~g} \cdot \mathrm{cm}^{-3}$ for each area of the original extension. Our results correspond to this value (regardless of the site), and in terms of density, this is very high quality wood, and these are fairly young trees that have not yet reached rotation age, and we can assume that the density will increase. A higher value for the Douglas fir is only mentioned by Dinwoodie [31] $-0.590 \mathrm{~g} \cdot \mathrm{cm}^{-3}$. Even so, Douglas fir does not exceed the larch value of $590 \mathrm{~kg} \cdot \mathrm{m}^{-3}$ [32], which has the highest density of domestic coniferous tree species. For pine wood, authors from the region specify a value of $0.510 \mathrm{~g} \cdot \mathrm{cm}^{-3}$ [32], and in this case, in terms of density, only afforested agricultural land produces a qualitatively comparable wood, again with the assumption that density will increase with increasing age. According to the literature, spruce achieves a value of $0.470 \mathrm{~g} \cdot \mathrm{cm}^{-3}$ [32], and both evaluated sites thus reached the corresponding density values.

The MOE result for Douglas fir does not achieve the values stated by Alden [30] at any of the sites. The value from the forest land only comes close to the data for the Douglas fir from the area of the Interior South: 10,300 MPa. Similarly, the spruce and the pine achieve lower values in comparison to the data, i.e., 11,000 MPa and 12,000 MPa respectively, which are mentioned in the literature [32].

The evaluated Douglas fir wood does not achieve any of the values from the areas of the original expansion stated by Alden [30], regardless of site. Likewise, the spruce and pine exhibited lower values compared to the literature [32]: $78 \mathrm{MPa}$ and $80 \mathrm{MPa}$.

Due to a different methodology of determination, it was not possible to compare the Douglas fir values with the data from the original sites. On the basis of a comparison with other works evaluating this property, the obtained value can be stated as average [33]. The values obtained for spruce and pine can be assumed to be lower on the basis of a comparison of $4.6 \mathrm{~J} \cdot \mathrm{cm}^{-2}$ and $4.0 \mathrm{~J} \cdot \mathrm{cm}^{-2}$ [32].

The authors often point to a lower wood density for former afforested agricultural land [23], and lower strength characteristics [21]. This is because of the fact that agricultural land usually contains a greater quantity (usually artificially supplied) of nutrients that result in a faster growth, which is reflected in the larger annual ring width, and thus for conifers, it is accompanied by a decrease in the density of such wood. This fact is confirmed by studies evaluating the effect of artificial fertilization 
of forest growth (analogy of nutrient delivery to agricultural crops) on wood properties, where it is clearly demonstrated that higher nutrient intake corresponds to a decrease in density and strength of the spruce, pine or the Douglas fir [34-36]. However, this may not be the norm, as proven by Bartoš [20] for spruce wood in the Czech Republic, and wood from such sites need not be regarded as less valuable. This is confirmed by our results. It should be noted that some authors obtained even better wood properties on former agricultural land [37].

The Douglas fir is clearly justified as a potential substitute for spruce wood because the Douglas fir dominates in all rated properties. The difference is particularly obvious in the density, where the difference is not only statistically significant, but also significant in terms of the utilization of the wood, and the site does not play a role here. Similar is the striking difference in the impact bending strength, both in terms of statistics and usability of wood. The difference between the Douglas fir and spruce is not as pronounced in MOE and MOR, mainly due to the differences that occurred with the Douglas fir depending on the site; nevertheless, the Douglas fir wood still achieves higher values for these properties.

The increasing trend of density, and hence strength characteristics, in the direction from the centre of the stem to the cambium, is characteristic of conifers due to the presence of juvenile wood $[38,39]$. This was observed for the Douglas fir [40], for spruce wood [41], for pines [42] and other conifers [43].

Density affects impact bending strength the least. In the case of the Douglas fir and the spruce, it can be stated that on forest soil the dependence of strength and elastic characteristics on density is greater. The more significant influence of density on strength characteristics was also confirmed by Jelonek [37] $\left(R^{2}=0.53\right)$.

\section{Conclusions}

Douglas fir is a promising tree species for Czech forestry. With the growing area of forests, the issue of the quality of wood originating from afforested former farmland is the focus. The aim of this study is to evaluate the wood properties of Douglas fir originating from such sites in contrast to native spruce and to some extent, pine. Although wood originating from former farm land is often regarded as inferior, this was not confirmed in most cases of our research, and our results are as follows.

In all of the tested properties, the Douglas fir had the highest values and clearly exceeds the evaluated domestic conifers. In term of density, it exceeds the spruce by more than $100 \mathrm{~kg} \cdot \mathrm{m}^{-3}$, and the value impact bending strength is also almost double.

The origin of the site plays no role at all in the case of the spruce. In the case of the Douglas fir, an impact was only observed for MOE and MOR, where higher values were obtained on forest soil.

Based on a comparison with literature, sites provide wood of adequate quality in terms of density for all tree species and impact bending strength for the Douglas fir. For the remaining properties, the values are lower than those reported in the literature.

The position in the stem proved to be another factor that significantly influences the variability of wood properties, as the values increase with increasing distance from the centre of the stem. These trends are primarily striking for the Douglas fir and pine. The influence of the vertical position in the stem was not confirmed.

The dependence of the measured mechanical properties on density is the highest for bending strength. The highest value, $R^{2}=0.57$, was obtained for the pine.

Acknowledgments: The authors are grateful for the support from the project NAZV QJ1520299"Applying Douglas fir in forest management of the Czech Republic", and the project NAZV QJ1520037 "Increasing the adaptability of pine (Pinus sylvestris L.) silviculture in the conditions of the Czech Republic".

Author Contributions: A. Zeidler conceived and designed the experiments; A. Zeidler was responsible for field data and the testing material collection; O. Schönfelder performed the tests and analysed the data; V. Borůvka performed statistical analyses and wrote the first draft of Results; A. Zeidler finalised the data analyses and their interpreting and completed the manuscript. 
Conflicts of Interest: The authors declare no conflict of interest. The founding sponsors had no role in the design of the study; in the collection, analyses, or interpretation of data; in the writing of the manuscript, and in the decision to publish the results.

\section{References}

1. Skaloš, J.; Engstová, B.; Trpáková, I.; Šantrůčková, M.; Podrázský, V. Long-term changes in forest cover 1780-2007 in central Bohemia, Czech Republic. Eur. J. For. Res. 2012, 131, 871-884. [CrossRef]

2. Vopravil, J.; Podrázský, V.; Batysta, M.; Novák, P.; Havelková, L.; Hrabalíková, M. Identification of agricultural soils suitable for afforestation in the Czech Republic using a soil database. J. For. Sci. 2015, 61, 141-147. [CrossRef]

3. Podrázský, V.; Čermák, R.; Zahradník, D.; Kouba, J. Production of Douglas-fir in the Czech Republic based on national forest inventory data. J. For. Sci. 2013, 59, 398-404.

4. Šindelář, J.; Beran, F. K některým aktuálním problémům pěstování douglasky tisolisté (Remarks to some topical problems of Douglas-fir cultivation). In Lesnický průvodce (Forests guide) 2004/3; VÚLHM: Strnady, Czech Republic, 2004. (In Czech)

5. Kubeček, J.; Štefančík, I.; Podrázský, V.; Longauer, R. Results of the research of Douglas-fir in the Czech Republic and Slovakia: A review. For. J. 2014, 60, 120-129. [CrossRef]

6. Vašíček, J. Data of Douglas-fir in the Czech Republic. (Data o douglasce tisolisté v ČR). Lesnická práce 2014, 93, 17. (In Czech)

7. Podrázský, V.; Remeš, J.; Sloup, R.; Pulkrab, K.; Novotná, S. Douglas-fir-Partial substitution for declining conifer timber supply—review of Czech data. Wood Res. 2016, 61, 525-530.

8. Podrázský, V.; Zahradník, D.; Remeš, J. Potential consequences of tree species and age structure changes of forests in the Czech Republic-Review of forest inventory data. Wood Res. 2014, 59, 483-490.

9. Pulkrab, K.; Sloup, R.; Podrázský, V. Production potential of the forests in the Czech Republic. BioResources 2015, 10, 4711-4725. [CrossRef]

10. Synek, M.; Vašíček, J.; Zeman, M. Outlook of logging perspectives in the Czech Republic for the period 2013-2032. J. For. Sci. 2014, 60, 372-381.

11. Holubík, O.; Podrázský, V.; Vopravil, J.; Khel, T.; Remeš, J. Effect of agricultural land afforestation and tree species composition on the soil reaction, total organic carbon and nitrogen content in the uppermost mineral soil profile. Soil Water Res. 2014, 9, 192-200.

12. Podrázský, V.; Holubík, O.; Vopravil, J.; Khel, T.; Moser, W.K.; Prknová, H. Effects of afforestation on soil structure formation in two climatic regions of the Czech Republic. J. For. Sci. 2015, 61, 225-234.

13. Podrázský, V.; Fulín, M.; Prknová, H.; Beran, F.; Třeštík, M. Changes of agricultural land characteristics as a result of afforestation using introduced tree species. J. For. Sci. 2016, 62, 72-79. [CrossRef]

14. Artemyeva, Z.; Zigova, A.; Kirillova, N.; Št’astný, M.; Holubík, O.; Podrázský, V. Evaluation of aggregate stability of Haplic Stagnosols using dynamic light scattering, phase analysis light scattering and color coordinates. Arch. Agron. Soil Sci. 2017, 63, 1-14. [CrossRef]

15. Kupka, I.; Podrázský, V.; Kubeček, J. Soil-forming effect of Douglas fir at lower altitudes. J. For. Sci. 2013, 59, 345-351.

16. Fulín, M.; Novotný, P.; Podrázský, V.; Beran, F.; Dostál, J.; Jehlička, J. Evaluation of the provenance plot "Hrubá Skála" (Northern Bohemia) with grand fir at the age of 36 years. J. For. Sci. 2017, 63, 75-87.

17. Podrázský, V.; Martiník, A.; Matějka, K.; Viewegh, J. Effects of Douglas-fir (Pseudotsuga menziesii [Mirb.] Franco) on understorey layer species diversity in managed forests. J. For. Sci. 2014, 60, 263-271.

18. Podrázský, V. Možná substituce smrku douglaskou v podmínkách České republiky (Possible substitution of spruce by Douglas fir in the conditions of the Czech Republic). In Proceedings of the Central European Silviculture, Dobruška, Czech Republic, 30-31 August 2016; pp. 99-104.

19. Remeš, J.; Zeidler, A. Production potential and wood quality of Douglas fir from selected sites in the Czech republic. Wood Res. 2014, 59, 509-520.

20. Bartoš, J.; Souček, J.; Kacálek, D. Comparison of wood properties of 50-year-old spruce stands on sites experiencing different land use in the past. Rep. For. Res. 2010, 55, 195-200.

21. Tomczak, A.; Jelonek, T. Radial variation in the wood properties of Scots pine (Pinus sylvestris L.) grown on former agricultural soil. For. Res. Pap. 2013, 74, 171-177. [CrossRef] 
22. Jelonek, T.; Pazdrowski, W.; Arasimowicz-Jelonek, M.; Tomczak, A. Properties of wood of Scots pine (Pinus sylvestris L.) growing on former farmlands. Sylwan 2010, 154, 299-311.

23. Johansson, T. Biomass production of Norway spruce (Picea abies (L.) Karst.) growing on abandoned farmland. Silv. Fenn. 1999, 33, 261-280. [CrossRef]

24. Podrázský, V.; Remeš, J.; Hart, V.; Moser, W.K. Production and humus form development in forest stands established on agricultural lands-Kostelec nad Černými lesy region. J. For. Sci. 2009, 55, 299-305.

25. ČSN 49 0108. Drevo. Zist'ovanie Hustoty (Wood. Determination of the Density); Český Normalizační Institut: Prague, Czech Republic, 1993. (In Czech)

26. ČSN 49 0103. Drevo. Zist'ovanie Vlhkosti pri Fyzikálnych a Mechanických Skúškach (Wood. Determination of Moisture Content at Physical and Mechanical Testing); Vydavatelství Úřadu pro Normalizaci a Měření: Prague, Czech Republic, 1979. (In Czech)

27. ČSN 49 0115. Drevo. Zist'ovanie Medze Pevnosti v Statickom Ohybe (Wood. Determination of Ultimate Strength in Flexure tests); Vydavatelství Úřadu pro Normalizaci a Měření: Prague, Czech Republic, 1979. (In Czech)

28. ČSN 49 0116. Drevo. Metóda Zist'ovania Modulu Pružnosti pri Statickom Ohybe (Wood. Determination of the Modulus of Elasticity in Static Bending); Vydavatelství Úřadu pro Normalizaci a Měření: Prague, Czech Republic, 1982. (In Czech)

29. ČSN 49 0117. Drevo. Rázová Húževnatost' v Ohybe (Wood. Impact Strength in Bending); Vydavatelství Úřadu pro Normalizaci a Měření: Prague, Czech Republic, 1980. (In Czech)

30. Alden, H.A. Softwoods of North. America; Forest Service, Forest Products Laboratory: Madison, WI, USA, 1997.

31. Dinwoodie, J.M. Timber: Its Nature and Behavior; Taylor and Francis: New York, NY, USA, 2000.

32. Wagenführ, R. Holzatlas; Fachbuchverlag: Leipzig, Germany, 2000.

33. Hapla, F. Douglasie-eine Bauholzart mit Zukunft. Forst und Holz 2000, 55, 728-732.

34. Mäkinen, H.; Hynynen, J. Wood density and tracheid properties of Scots pine: Responses to repeated fertilization and timing of the first commercial thinning. For.: Int. J. For. Res. 2014, 87, 437-447. [CrossRef]

35. Lundgren, C. Microfibril angle and density patterns of fertilized and irrigated Norway spruce. Silv. Fenn. 2014, 38, 107-117. [CrossRef]

36. Jozsa, L.A.; Brix, H. The effects of fertilization and thinning on wood quality of a 24-year-old Douglas-fir stand. Can. J. For. Res. 1989, 19, 1137-1145. [CrossRef]

37. Jelonek, T.; Tomczak, A.; Jakubowski, M.; Pazdrowski, W. Properties of Scots pine (Pinus sylvestris L.) timber growing on former arable and forest land. Biosci. Wood Growing Syst. Wood Ind. 2005, 4, 35-47. [CrossRef]

38. Zobel, B.J.; van Buitenen, J.P. Wood Variation, Its Causes and Control; Springer: Berlin, Germany, 1989.

39. Tsoumis, G. Science and Technology of Wood-Structure, Properties, Utilization; Chapman and Hall: New York, NY, USA, 1991.

40. Langum, CH.; Yadama, V.; Lowell, E.C. Physical and mechanical properties of young-growth Douglas-fir and western hemlock from western Washington. For. Prod. J. 2009, 59, 37-47. [CrossRef]

41. Jyske, T.; Mäkinen, H.; Saranpää, P. Wood density within Norway spruce stems. Silv. Fenn. 2008, 42, 439-455. [CrossRef]

42. Machado, J.S.; Cruz, H.P. Within stem variation of Maritime Pine timber mechanical properties. Eur. J. Wood Wood Prod. 2005, 63, 154-159. [CrossRef]

43. DeBell, D.S.; Singleton, R.; Gartner, B.L.; Marshall, D.D. Wood density of young-growth western hemlock: Relation to ring age, radial growth, stand density, and site quality. Can. J. For. Res. 2004, 34, 2433-2442. [CrossRef]

(C) 2017 by the authors. Licensee MDPI, Basel, Switzerland. This article is an open access article distributed under the terms and conditions of the Creative Commons Attribution (CC BY) license (http:/ / creativecommons.org/licenses/by/4.0/). 